\title{
Impact of granule size distribution on nitrous oxide production in autotrophic nitrogen
} removal granular reactor

\author{
Chen, Xueming; Sin, Gürkan; Ni, Bing-Jie
}

\section{Published in:}

Science of the Total Environment

Link to article, DOI:

10.1016/j.scitotenv.2019.06.490

Publication date:

2019

Document Version

Peer reviewed version

Link back to DTU Orbit

\section{Citation (APA):}

Chen, X., Sin, G., \& Ni, B-J. (2019). Impact of granule size distribution on nitrous oxide production in autotrophic nitrogen removal granular reactor. Science of the Total Environment, 689, 700-708.

https://doi.org/10.1016/j.scitotenv.2019.06.490

\section{General rights}

Copyright and moral rights for the publications made accessible in the public portal are retained by the authors and/or other copyright owners and it is a condition of accessing publications that users recognise and abide by the legal requirements associated with these rights.

- Users may download and print one copy of any publication from the public portal for the purpose of private study or research.

- You may not further distribute the material or use it for any profit-making activity or commercial gain

- You may freely distribute the URL identifying the publication in the public portal 


\section{Accepted Manuscript}

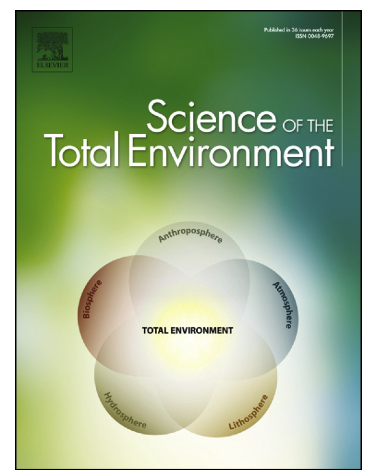

Xueming Chen, Gürkan Sin, Bing-Jie Ni

S0048-9697(19)33063-3

PII: https://doi.org/10.1016/j.scitotenv.2019.06.490

DOI: STOTEN 33144

Reference:

Science of the Total Environment

To appear in:

29 May 2019

Received date:

23 June 2019

Revised date:

28 June 2019

Accepted date:

Please cite this article as: X. Chen, G. Sin and B.-J. Ni, Impact of granule size distribution on nitrous oxide production in autotrophic nitrogen removal granular reactor, Science of the Total Environment, https://doi.org/10.1016/j.scitotenv.2019.06.490

This is a PDF file of an unedited manuscript that has been accepted for publication. As a service to our customers we are providing this early version of the manuscript. The manuscript will undergo copyediting, typesetting, and review of the resulting proof before it is published in its final form. Please note that during the production process errors may be discovered which could affect the content, and all legal disclaimers that apply to the journal pertain. 


\title{
Impact of Granule Size Distribution on Nitrous Oxide Production in Autotrophic
}

\section{Nitrogen Removal Granular Reactor}

\author{
Xueming Chen ${ }^{1}$, Gürkan $\mathrm{Sin}^{1}{ }^{1}$, , Bing-Jie $\mathrm{Ni}^{2}{ }^{2} *$
}

${ }^{1}$ Process and Systems Engineering Center (PROSYS), Department of Chemical and Biochemical Engineering, Technical University of Denmark, 2800 Kgs. Lyngby, Denmark

${ }^{2}$ Centre for Technology in Water and Wastewater, School of Civil and Environmental Engineering, University of Technology Sydney, Sydney, NSW 2007, Australia

\section{*Corresponding authors:}

Dr. Bing-Jie Ni, Phone: +61 29514 7401, E-mail: bingjieni@gmail.com

Dr. Gürkan Sin, Phone: +45 2381 1148, E-mail: gsi@kt.dtu.dk 


\section{ABSTRACT}

This work applied an approach with reactor compartmentation and artificial diffusion to study the impact of granule size distribution on the autotrophic granular reactor performing partial nitritation and anaerobic ammonium oxidation with focus on the nitrous oxide $\left(\mathrm{N}_{2} \mathrm{O}\right)$ production. The results show that the microbial community and the associated $\mathrm{N}_{2} \mathrm{O}$ production rates in the granular structure are significantly influenced by the granule size distribution. Heterotrophic bacteria growing on microbial decay products tend to be retained and contribute to $\mathrm{N}_{2} \mathrm{O}$ consumption in relatively small granules. Ammonium-oxidizing bacteria are mainly responsible for $\mathrm{N}_{2} \mathrm{O}$ production via two pathways in granules of different sizes. Under the conditions studied, such heterogeneity in the granular structure disappears when the number of granule size classes considered reaches more than 4 , where heterotrophic bacteria are completely outcompeted in the granules. In general, larger granules account for a higher portion of the net $\mathrm{N}_{2} \mathrm{O}$ production, while the trend regarding the volumetric contribution of each granule size class changes with a varied number of granule size classes, due to the different contributions of relevant $\mathrm{N}_{2} \mathrm{O}$ production pathways (with the heterotrophic denitrification pathway being the most decisive). Overall, with the increasing extent of granule size distribution, the nitrogen removal efficiency decreases slightly but consistently, whereas the $\mathrm{N}_{2} \mathrm{O}$ production factor increases until the number of granule size classes reaches 4 or above. Practical implications of this work include: i) granules should be controlled as well-distributed as possible in order to obtain high nitrogen removal whilst minimizing $\mathrm{N}_{2} \mathrm{O}$ production; ii) granule size distribution should be considered carefully and specifically when modelling $\mathrm{N}_{2} \mathrm{O}$ production/emission from the autotrophic nitrogen removal granular reactor.

Keywords: Autotrophic nitrogen removal granular reactor; granule size distribution; modelling; $\mathrm{N}_{2} \mathrm{O}$ production factor 


\section{INTRODUCTION}

The combination of partial nitritation $(\mathrm{PN})$ by ammonium-oxidizing bacteria $(\mathrm{AOB})$ and anaerobic ammonium oxidation (Anammox) represents a sustainable autotrophic nitrogen removal technology that has been commonly regarded as superior to the conventional nitrification/denitrification process for its cost-effectiveness in energy supply, sludge disposal, and resource recovery (Jetten et al., 2001; Kartal et al., 2010; Kuenen, 2008; Sliekers et al., 2002). Considering the relatively slow growth of Anammox bacteria and the difference between $\mathrm{AOB}$ and Anammox bacteria in the affinity for oxygen, granular sludge is particularly suitable for retaining $\mathrm{AOB}$ and Anammox bacteria simultaneously and sufficiently in a single-stage autotrophic nitrogen removal system, where the creation of spatially separated aerobic and anoxic zones is driven by dissolved oxygen (DO) concentration gradient inside granules (Lu et al., 2018).

Nevertheless, the widely-documented nitrous oxide $\left(\mathrm{N}_{2} \mathrm{O}\right)$ emissions (Ali et al., 2016; Blum et al., 2018; Castro-Barros et al., 2015; Domingo-Félez et al., 2014; Joss et al., 2009; Kampschreur et al., 2009; Ma et al., 2017; Sliekers et al., 2002) have brought about a significant uncertainty to the sustainable application and operation of PN/Anammox systems. $\mathrm{N}_{2} \mathrm{O}$ is known as a potent greenhouse gas with a global warming potential 265 times higher than carbon dioxide (IPCC, 2014) as well as a major scavenger of stratospheric ozone, thus contributing to the ozone layer depletion (Ravishankara et al., 2009). In PN/Anammox systems, AOB haven been regarded as the main contributor to $\mathrm{N}_{2} \mathrm{O}$ production through the hydroxylamine $\left(\mathrm{NH}_{2} \mathrm{OH}\right)$ pathway or/and the AOB denitrification pathway, while Anammox bacteria have been identified as incapable of producing $\mathrm{N}_{2} \mathrm{O}$ (Kartal et al., 2006). Moreover, despite the inorganic influent conditions, heterotrophic bacteria (HB) might still grow on microbial decay products accumulated in the granular structure (Lotti et al., 2014; Mozumder 
et al., 2014; $\mathrm{Ni}$ et al., 2012). Consequently, in addition to its primary positive contribution to nitrogen removal through reducing nitrate produced by Anammox bacteria, the co-occurrence of $\mathrm{HB}$ might play a significant role in regulating $\mathrm{N}_{2} \mathrm{O}$ production in autotrophic nitrogen removal systems, as $\mathrm{N}_{2} \mathrm{O}$ has been proved as an obligate intermediate of the sequential heterotrophic denitrification process (Hanaki et al., 1992; Ni et al., 2016). Further complicating the implementation of the autotrophic nitrogen removal granular system is the uncertainty associated with granule size distribution. Granule size is an important indicator of the granule surface to volume ratio that determines the mass transport of solutes in the granular biofilm, thus regulating the reactor performance (Chen et al., 2019; Volcke et al., 2012). A previous study by Liu et al. (2017) have demonstrated the influence of granule size distribution on the nitrogen removal performance of a similar granular reactor. However, little has been known regarding the impact of granule size distribution on the $\mathrm{N}_{2} \mathrm{O}$ production from the autotrophic granular reactor performing PN/Anammox.

Mathematical modelling, a reliable tool to study biological wastewater treatment systems (Kuriqi, 2014; Kuriqi et al., 2016), has been commonly applied to explore $\mathrm{N}_{2} \mathrm{O}$ production from various reactor configurations. However, when it comes to modelling granular reactors, a uniform granule size is assumed in most cases, even though the actual granules tend to follow certain size distribution (Volcke et al., 2012; Zhu et al., 2018b). So far, two main approaches have been proposed to simulate granule size distribution in granular reactors using Aquasim (Reichert, 1998), simulation software widely used for one-dimensional multisubstrate and multi-species biofilm modelling. Based on proper compartmentation of a reactor that captures difference in biofilm thickness, the first approach by Volcke et al. (2012) cross-links compartments using advective links, while the second approach by Baeten et al. (2017) connects compartments with diffusive links to mimic complete mixing in bulk liquid. 
The availability of these approaches makes it possible to systematically assess the $\mathrm{N}_{2} \mathrm{O}$ production from the autotrophic granular reactor in consideration of granule size distribution.

To this end, a previously-developed $\mathrm{N}_{2} \mathrm{O}$ model capable of describing relevant mechanisms in autotrophic nitrogen removal systems (Chen et al., 2019) was applied in this work. With granule size distribution being considered in accordance with Baeten et al. (2017), the impact of granule size distribution on $\mathrm{N}_{2} \mathrm{O}$ production was investigated for the autotrophic nitrogen removal granular reactor. This work is expected to gain useful insights into 1) future control over granule size characteristics in order to mitigate $\mathrm{N}_{2} \mathrm{O}$ production/emission from the autotrophic nitrogen removal granular reactor and 2) good practice in modelling $\mathrm{N}_{2} \mathrm{O}$ production/emission from the autotrophic nitrogen removal granular reactor based on the extent of granule size distribution.

\section{MATERIALS AND METHODS}

\subsection{Model Describing Nitrous Oxide Production during Autotrophic Nitrogen Removal}

The mathematical model whose validity has been verified using experimental datasets in our previous work (Chen et al., 2019) was directly adopted in this work to describe the joint mechanisms of relevant contributing microorganisms, including AOB, nitrite-oxidizing bacteria (NOB), HB, and Anammox bacteria, in an autotrophic nitrogen removal granular reactor. In brief, three pathways are considered for $\mathrm{N}_{2} \mathrm{O}$ production, which include 1) the AOB denitrification pathway, where $\mathrm{N}_{2} \mathrm{O}$ is the final product, 2) the $\mathrm{NH}_{2} \mathrm{OH}$ pathway by AOB, where $\mathrm{N}_{2} \mathrm{O}$ is a byproduct of incomplete oxidation of $\mathrm{NH}_{2} \mathrm{OH}$ via $\mathrm{NO}$ to $\mathrm{NO}_{2}{ }^{-}$, and 3) the sequential reduction of bioactive nitrogen oxides to $\mathrm{N}_{2}$ by $\mathrm{HB}$, where $\mathrm{N}_{2} \mathrm{O}$ is an intermediate. 
Collectively, as shown in Table S1 in the supporting information (SI), the model contains 15 state variables: 6 solid components and 9 soluble components. The interactive relationships among these components mediated by different contributing microorganisms involve altogether 17 process reactions (Table S2 in the SI), leading to substrate consumption, product formation, and biomass growth/decay. The corresponding process reaction rates, which are described by either substrate-dependent Monod equation or first-order equation with respect to biomass, are listed in Table S3 (SI). Together with their values, units, and sources, the stoichiometric and kinetic parameters involved in the model are summarized in Table S4 (SI).

\subsection{Approach to Modelling Granule Size Distribution}

To model granule size distribution in a well-mixed granular reactor, the configuration presented in Fig. 1 was implemented in Aquasim (Reichert, 1998) through compartmentation of the reactor and utilization of the diffusive link. As explained by Baeten et al. (2017), the introduced mass transfer rate $\left(R_{d}\right)$ of a compound between two diffusively linked compartments, which is analogous to the well-known gas-liquid mass transfer model, is calculated by $R_{d}=q_{e x}\left(S_{1}-S_{2}\right)$, where $S_{1}$ is the concentration in the first compartment, $S_{2}$ is the concentration in the second compartment, and $q_{e x}$ is a predefined, sufficiently high exchange coefficient. Specifically, depending on the number of granule size classes ( $\mathrm{n} \geq 2)$ to be considered, the implementation (i.e., Fig. 1) in Aquasim could be achieved by the following steps:

1) Create one biofilm compartment for every granule size class as well as one mixed compartment.

2) Connect the inflow (Q) and outflow (Q) to the mixed compartment, and connect every biofilm compartment to the mixed compartment with a diffusive link. 
3) Divide the total reactor volume (V) equally among all the different compartments, each therefore having a volume of $\mathrm{V} /(\mathrm{n}+1)$.

4) Divide the total number of granules (N) equally among all the different biofilm compartments, each therefore having $\mathrm{N} / \mathrm{n}$ granules.

5) Assign the same, sufficiently high diffusive exchange coefficient (e.g., $1000000 \mathrm{~m}^{3} / \mathrm{d}$ ) to every soluble and solid component for all the diffusive links, thus ensuring nearly identical (maximum allowable difference of $1 \%$ ) concentrations of all components in the bulk liquid of all the different compartments.

As discussed in Baeten et al. (2017), this approach with diffusive links (i.e., Fig. 1) is advantageous over the previous advection-based approach proposed by Volcke et al. (2012), which uses reasonably high advective links to connect the bulk liquid of compartments to mimic the mixing, in its elimination of the trade-off between mixing and correct mass balance, thus leading to higher reliability and efficiency, wider applicability, easier implementability, and a lower risk for numerical errors in Aquasim. With this novel approach, the impact of granule size distribution on $\mathrm{N}_{2} \mathrm{O}$ production in the autotrophic nitrogen removal granular reactor could be reliably investigated, which is detailed in the following section.

\subsection{Reactor Setup and Modelling Scenarios}

The referencing settings in our previous work (Chen et al., 2019) which could lead to a total nitrogen (TN) removal efficiency of around 90\% in the autotrophic nitrogen removal granular reactor operated in the continuous mode were directly applied in this work. Specifically, as indicated in Table S5 (SI), the total reactor volume (V) was considered to be fixed at $1 \mathrm{~m}^{3}$, including $0.2 \mathrm{~m}^{3}$ of granules and $0.8 \mathrm{~m}^{3}$ of bulk liquid. The inflow and outflow rate (Q) was considered to be $1 \mathrm{~m}^{3} / \mathrm{d}$, corresponding to a hydraulic retention time of 1 day. The inflow was 
modelled to only constitute $\mathrm{NH}_{4}{ }^{+}$at the concentration of $500 \mathrm{~g}-\mathrm{N} / \mathrm{m}^{3}$ in the absence of biodegradable organics. The bulk DO concentration was kept constant at $0.25 \mathrm{~g} / \mathrm{m}^{3}$.

To study the impact of granule size distribution, five simulation scenarios were performed in this work (see Fig. S1 in the SI). The nearly normal distribution of granule size used to design the simulation scenarios was generated with reference to a lab-scale granular reactor and is presented in Fig. S2 in the SI. Table 1 summarizes the detailed features of reactors with different granule size classes considered for the five scenarios. Scenario 1 investigated the autotrophic granular reactor with a uniform granule size of $500 \mu \mathrm{m}$ (radius), representing one granule size class. Through dividing the total volume of granules (i.e., $0.2 \mathrm{~m}^{3}$ ) by the volume of each granule, the total number of granules $(\mathrm{N})$ was calculated at $3.82 \times 10^{8}$. Scenarios 2 to 5 probed into the autotrophic granular reactor with 2 to 5 granule size classes, respectively. The granule size (radius) in each granule size class was selected so that the total granule volume of all granule size classes equaled to $0.2 \mathrm{~m}^{3}$. This setting ensured the same average granule size for all the simulations scenarios, thus making the extent of granule size distribution the only variable to be studied. For the sake of clear presentation, granule size class is referred to as size class $\mathrm{X} / \mathrm{Y}$, where $\mathrm{X}$ stands for the $\mathrm{X}$ th granule size class while $\mathrm{Y}$ represents the total number of granule size classes modelled for a particular autotrophic granular reactor, in the following sections. The granule size (radius) of size class $(\mathrm{X}+1) / \mathrm{Y}$ was defined as significantly higher than that of size class $\mathrm{X} / \mathrm{Y}$.

For each simulation scenario, the initial concentrations of all 9 soluble components in the autotrophic granules as well as the bulk liquid were assumed to be zero, while each of the four contributing microorganisms and the abiotic organics (inert and slowly biodegradable organics) was assumed to take up $20 \%$ of the initial solid chemical oxygen demand (COD) in 
the granules. All the simulation scenarios assumed a biomass density of $100000 \mathrm{~g}-\mathrm{COD} / \mathrm{m}^{3}$ and a granule porosity of 0.75 (Koch et al., 2000), thus giving rise to a total solid concentration in the autotrophic granular reactor of $5000 \mathrm{~g}-\mathrm{COD} / \mathrm{m}^{3}$. As provided in Table S5 (SI), diffusion of soluble components in the granule matrix was set with the introduction of reduced diffusion coefficients in water, while zero-flux of soluble components was considered at the granule center. Similar to the previous comparative studies (Chen et al., 2019; Sabba et al., 2017; Sabba et al., 2015), the mass transfer resistance through the liquid boundary layer was neglected for all soluble components, meaning that the concentration at the granule surface was identical to that in the bulk liquid. The steady-state granule size was controlled by the surface detachment velocity reported in Ni and Yuan (2013) without considering re-attachment of detached solids. For all the model simulations, venting of the produced $\mathrm{N}_{2} \mathrm{O}$ was assumed to be achieved in the continuous outflow leaving the autotrophic granular reactor as well as through liquid-to-gas transfer of $\mathrm{N}_{2} \mathrm{O}$, which was modelled by incorporating a gas-liquid mass transfer equation $\left(R_{N 2 O}\right)$ mediated by the mass transfer coefficient $\left(K_{L} a\right)$ and the Henry's law constant $(H)$ (Schulthess and Gujer, 1996) into the bulk liquid of all the different compartments.

$$
R_{N 2 O}=K_{L} a_{N 2 O}\left(S_{N 2 O}-\frac{S_{N 2 O, a i r}}{H_{N 2 O}}\right)
$$

where $K_{L} a_{N 2 O}$ was assumed at $20 \mathrm{~d}^{-1}, S_{N 2 O \text {, air }}$ was $0.0003 \mathrm{~g}-\mathrm{N} / \mathrm{m}^{3}$, and $H_{N 2 O}$ was 1.9 (Chen et al., 2019).

All the model simulations were run to reach steady-state conditions indicated by constant effluent concentrations, $\mathrm{N}_{2} \mathrm{O}$ production, granule size, and microbial composition. The main indexes used to evaluate the autotrophic granule reactor performance were the TN removal 
efficiency (the percentage ratio of dinitrogen formed to influent ammonium) and the $\mathrm{N}_{2} \mathrm{O}$ production factor (the percentage ratio of $\mathrm{N}_{2} \mathrm{O}$ formed to ammonium removed). It should be noted that when calculating the $\mathrm{N}_{2} \mathrm{O}$ formed, both the $\mathrm{N}_{2} \mathrm{O}$ leaving the system together with the outflow and the $\mathrm{N}_{2} \mathrm{O}$ being transferred to the atmosphere were taken into account.

\section{RESULTS}

\subsection{Impact of Granule Size Distribution on $\mathrm{TN}$ Removal and $\mathrm{N}_{2} \mathrm{O}$ Production in Autotrophic Granular Reactor}

The impact of granule size distribution in the form of a varied number of granule size classes considered (i.e., Scenarios 1 to 5 in Table 1) on the autotrophic granule reactor was assessed in terms of the treatment performance (i.e., TN removal and $\mathrm{N}_{2} \mathrm{O}$ production) and the composition of microorganisms and their associated contributions to $\mathrm{N}_{2} \mathrm{O}$ production, with results demonstrated in Fig. 2. When the granules are of a uniform size (i.e., only 1 granule size class in the reactor), $\mathrm{AOB}(7 \%)$, Anammox bacteria (91\%), and $\mathrm{HB}(2 \%)$ jointly dominate the active biomass in the autotrophic granules, leading to a TN removal efficiency of $90.1 \%$ (Fig. 2A). The increase in the number of granule size classes to 2 brings no significant change to the active microbial community structure and therefore leads to a nearly unchanged TN removal efficiency of $89.8 \%$. However, when the extent of granule size distribution intensifies by increasing the number of granule size classes to 3 , the abundance of $\mathrm{HB}$ decreases to $1 \%$, while that of Anammox bacteria increases to $92 \%$. Although the abundance of $\mathrm{AOB}$ remains almost stable at $7 \%$, the corresponding $\mathrm{TN}$ removal efficiency drops to $88.7 \%$ (Fig. 2A). Further increasing the number of granule size classes to 4 and 5 tends to wash $\mathrm{HB}$ out of the reactor, rendering the abundance of $\mathrm{HB}$ of lower than $0.1 \%$; AOB (7\%) and Anammox bacteria (93\%) are therefore the dominant contributing microorganisms in the autotrophic granules. The resultant TN removal efficiency decreases to 
around $87.0 \%$. As shown in Fig. 2A, despite the variation in the number of granules size classes considered, there is always no presence of NOB in the autotrophic granules.

Comparatively, a distinct trend has been observed in Fig. $2 \mathrm{~B}$ for the $\mathrm{N}_{2} \mathrm{O}$ production dynamics with respect to the number of granule size classes. On the condition of 1 granule size class, the lowest $\mathrm{N}_{2} \mathrm{O}$ production factor is achieved at $1.8 \%$. Judged by their contributions to $\mathrm{N}_{2} \mathrm{O}$ turnover, $\mathrm{AOB}$ result in $\mathrm{N}_{2} \mathrm{O}$ formation while $\mathrm{HB}$ lead to $\mathrm{N}_{2} \mathrm{O}$ consumption. When the extent of granule size distribution is still low with the number of granule size classes of 2 , the $\mathrm{N}_{2} \mathrm{O}$ production factor slightly increases to $1.9 \%$, due to the less than $1 \%$ exchange between the contributions of $\mathrm{AOB}$ and $\mathrm{HB}$ to $\mathrm{N}_{2} \mathrm{O}$ turnover (Fig. $2 \mathrm{~B}$ ). Further increasing the number of granule size classes diminishes the negative contribution of $\mathrm{HB}$ to $\mathrm{N}_{2} \mathrm{O}$ production, hence the rising $\mathrm{N}_{2} \mathrm{O}$ production factor. At the number of granule size classes of 4 , the $\mathrm{N}_{2} \mathrm{O}$ production factor reaches the maximum value of $2.9 \%$, with less than $1 \%$ negative contribution of $\mathrm{HB}$ to $\mathrm{N}_{2} \mathrm{O}$ turnover. The highest extent of granule size distribution at the number of granule size classes of 5 only further reinforces the deprivation of the negative contribution of $\mathrm{HB}$ to $\mathrm{N}_{2} \mathrm{O}$ production without significantly affecting the full $\mathrm{N}_{2} \mathrm{O}$ production by AOB. Consequently, the $\mathrm{N}_{2} \mathrm{O}$ production factor stays around 2.9\% (Fig. 2B).

\subsection{Profiles of Solid Components and $\mathrm{N}_{2} \mathrm{O}$ Production Rates in Granules of Different Sizes}

The detailed characteristics of granules in each granule size class of the autotrophic granular reactor considering a varied number of granule size classes were generated to assist the interpretation of the overall impact of granule size distribution on the autotrophic granular reactor. Fig. 3 delineates the fraction profiles of the 6 solid components in each granule size class, while Fig. 4 presents the corresponding profiles of relevant $\mathrm{N}_{2} \mathrm{O}$ production rates 
associated with $\mathrm{AOB}$ and $\mathrm{HB}$ as $\mathrm{N}_{2} \mathrm{O}$ mediators. For the sake of easy presentation in Fig. 4, " $r$ " refers to the rate of individual $\mathrm{N}_{2} \mathrm{O}$ production process, with subscript denoting the $\mathrm{N}_{2} \mathrm{O}$ related conversion process and superscript denoting the contributing microorganism, while " $\mathrm{R}$ " indicates the net $\mathrm{N}_{2} \mathrm{O}$ production rate mediated by certain contributing microorganism specified by superscript. A positive " $r$ " or " $\mathrm{R}$ " represents $\mathrm{N}_{2} \mathrm{O}$ production while a negative " $\mathrm{r}$ " or " $\mathrm{R}$ " means $\mathrm{N}_{2} \mathrm{O}$ consumption.

\subsubsection{Profiles of solid components in different granule size classes}

In size class $1 / 1$ (Fig. 3A), AOB and HB only exist at the granule surface, with fractions decreasing towards the granule center. The same trend has been observed for inert organics $\left(\mathrm{X}_{\mathrm{I}}\right)$, the formation of which is mediated by HB. As a result, towards the granule center, the dominant fraction of Anammox bacteria first increases and then decreases due to the emerging presence of slowly biodegradable organics $\left(\mathrm{X}_{\mathrm{S}}\right)$ in the inner part of granules. When granule size distribution is considered, significant differences exist between reactors with different numbers of granule size classes as well as between different granule size classes within the same reactor, as exhibited in Figs. 3B-3O. For the granular reactor with 2 granule size classes, Anammox bacteria solely dominate the inner part in size class 1/2 (Fig. 3B), while they occupy the inner part with the considerable joint presence of $\mathrm{X}_{\mathrm{S}}$ in size class $2 / 2$ (Fig. 3C). The fraction of $\mathrm{HB}$, which coexist with AOB and Anammox bacteria at the granule surface, is much higher in size class $1 / 2$ than size class $2 / 2$. The profiles of solid components in size classes 1/3 (Fig. 3D) and 2/3 (Fig. 3E) are similar to those observed in size classes 1/2 (Fig. 3B) and $2 / 2$ (Fig. 3C), respectively. The major difference in size class $3 / 3$ from the aforementioned granule size classes lies in the disappearance of HB from the granules, compensated by a significant fraction of $\mathrm{X}_{\mathrm{S}}$ at the granule surface (Fig. 3F). For the granular reactor with 4 granule size classes, the profiles of solid components in size class $1 / 4$ (Fig. 3G) 
are analogous to those in size classes $2 / 2$ (Fig. 3C) and 2/3 (Fig. 3E), where a small fraction of HB exists at the granule surface. Nevertheless, the profiles of solid components in size classes 2/4 to 4/4 (Figs. 3H-3J) are comparable to each other and resemble those in size class 3/3 (Fig. 3F), where $\mathrm{HB}$ are absent from the granules. When the number of granule size classes reaches 5, all the granule size classes exhibit comparable trends regarding the fraction profiles of solid components (Figs. 3K-3O). These profiles are similar to those in granule size classes with relatively large granule sizes in the reactor with 3 or 4 granule size classes, e.g., size class 3/3 (Fig. 3F) and size classes 2/4 to 4/4 (Figs. 3H-3J). It should be noted that NOB are not able to grow in the autotrophic granule reactor under the operational conditions studied, regardless of the extent of granule size distribution.

\subsubsection{Profiles of $\mathrm{N}_{2} \mathrm{O}$ production rates in different granule size classes}

As demonstrated in Fig. $4 \mathrm{~A}, \mathrm{~N}_{2} \mathrm{O}$ production only takes place at the granule surface where AOB and $\mathrm{HB}$ coexist in size class $1 / 1$. The net $\mathrm{N}_{2} \mathrm{O}$ production by $\mathrm{AOB}$ (i.e., the positive ) is derived from the joint contribution of both the AOB denitrification pathway () and the $\mathrm{NH}_{2} \mathrm{OH}$ pathway (), the latter of which possesses a higher rate. On the contrary, the net $\mathrm{N}_{2} \mathrm{O}$ consumption by $\mathrm{HB}$ (i.e., the negative ) is ascribed to the significant rate of $\mathrm{N}_{2} \mathrm{O}$ reduction to $\mathrm{N}_{2}$ (), compared to the marginal rate of $\mathrm{N}_{2} \mathrm{O}$ formation from $\mathrm{NO}$ (). The most distinct difference between size classes $1 / 2$ (Fig. 4B) and $2 / 2$ (Fig. 4C) lies in the rate of $\mathrm{N}_{2} \mathrm{O}$ reduction to $\mathrm{N}_{2}$ () which to the most degree determines the $\mathrm{N}_{2} \mathrm{O}$ consuming capability of $\mathrm{HB}$ (i.e., ): the magnitude of $\mathrm{r}_{\mathrm{N} 2 \mathrm{O} \rightarrow \mathrm{N} 2}^{\mathrm{HB}}$ is much higher in size class 1/2 (Fig. 4B) than size classes 2/2 (Fig. 4C). Similar to the trends about solid components observed in Section 3.2.1, the profiles of $\mathrm{N}_{2} \mathrm{O}$ production rates in size classes 1/3 (Fig. 4D) and 2/3 (Fig. 4E) are comparable to those revealed in size classes $1 / 2$ (Fig. 4B) and 2/2 (Fig. 4C), respectively. In size class $3 / 3$ (Fig. 4F), $\mathrm{N}_{2} \mathrm{O}$ is solely produced by AOB; $\mathrm{HB}$ stand no contribution to $\mathrm{N}_{2} \mathrm{O}$ 
production/consumption due to their washout from the granules (Fig. 3F). For the reactor with 4 granule size classes, $\mathrm{AOB}$ play a dominant role in $\mathrm{N}_{2} \mathrm{O}$ production accompanied by trace $\mathrm{N}_{2} \mathrm{O}$ consumption by $\mathrm{HB}$ in size class $1 / 4$ (Fig. $4 \mathrm{G}$ ), while AOB are solely responsible for $\mathrm{N}_{2} \mathrm{O}$ production via both pathways without any contribution by $\mathrm{HB}$ due to their absence in size classes 2/4 to 4/4 (Figs. 4H-4J). As shown in Figs. 4K-4O, in the reactor with 5 granule size classes, all the granule size classes without the presence of HB display comparable trends in terms of relevant $\mathrm{N}_{2} \mathrm{O}$ production rates, similar to size class $3 / 3$ (Fig. $4 \mathrm{~F}$ ) and size classes 2/4 to 4/4 (Figs. 4H-4J).

\subsection{Role of Each Granule Size Class in $\mathrm{N}_{2} \mathrm{O}$ Production in Autotrophic Granular Reactor}

Fig. 5 was generated to quantify the contribution (in percentage) of each granule size class of the granular reactor with 2 to 5 granule size classes to the net $\mathrm{N}_{2} \mathrm{O}$ production together with the associated contribution of each $\mathrm{N}_{2} \mathrm{O}$ production pathway to $\mathrm{N}_{2} \mathrm{O}$ turnover in each size class. In the reactor with 2 granule size classes (Fig. 5A), size class $1 / 2$ is responsible for $20 \%$ of the $\mathrm{N}_{2} \mathrm{O}$ production, with the $\mathrm{AOB}$ denitrification pathway, the $\mathrm{NH}_{2} \mathrm{OH}$ pathway, and the HB pathway each accounting for $23 \%, 41 \%$, and $-36 \%$ of $\mathrm{N}_{2} \mathrm{O}$ turnover. By comparison, size class $2 / 2$ takes up the remaining $80 \%$ of the $\mathrm{N}_{2} \mathrm{O}$ production, with the AOB denitrification pathway, the $\mathrm{NH}_{2} \mathrm{OH}$ pathway, and the $\mathrm{HB}$ pathway each occupying $32 \%, 55 \%$, and $-13 \%$ of $\mathrm{N}_{2} \mathrm{O}$ turnover. In the reactor with 3 granule size classes (Fig. 5B), size class $1 / 3$ is responsible for $11 \%$ of the $\mathrm{N}_{2} \mathrm{O}$ production, with $23 \%, 44 \%$, and $-33 \% \mathrm{~N}_{2} \mathrm{O}$ turnover contributed by the AOB denitrification pathway, the $\mathrm{NH}_{2} \mathrm{OH}$ pathway, and the $\mathrm{HB}$ pathway, respectively. In contrast, size class $2 / 3$ takes up $41 \%$ of the $\mathrm{N}_{2} \mathrm{O}$ production, with $32 \%, 58 \%$, and $-10 \% \mathrm{~N}_{2} \mathrm{O}$ turnover coming from the AOB denitrification pathway, the $\mathrm{NH}_{2} \mathrm{OH}$ pathway, and the $\mathrm{HB}$ pathway, respectively. The remaining $48 \%$ of the $\mathrm{N}_{2} \mathrm{O}$ production is initiated by size class $3 / 3$, 
with $35 \%$ and $65 \% \mathrm{~N}_{2} \mathrm{O}$ turnover contributed by the AOB denitrification pathway and the $\mathrm{NH}_{2} \mathrm{OH}$ pathway, respectively, without the presence of the HB pathway. As demonstrated in Fig. 5C, size classes $1 / 4$ to $4 / 4$ contribute to $12 \%, 20 \%, 30 \%$, and $38 \%$, respectively, of the $\mathrm{N}_{2} \mathrm{O}$ production. Except for size class $1 / 4$ which involves $-7 \% \mathrm{~N}_{2} \mathrm{O}$ turnover from the $\mathrm{HB}$ pathway, only the AOB denitrification pathway (33\%) and the $\mathrm{NH}_{2} \mathrm{OH}$ pathway $(67 \%)$ are effective in producing $\mathrm{N}_{2} \mathrm{O}$ in size classes $2 / 4$ to $4 / 4$. In the reactor with 5 granule size classes (Fig. 5D), size classes $1 / 5$ to $5 / 5$ conduce to different $\mathrm{N}_{2} \mathrm{O}$ production contributions (i.e., $7 \%$, $13 \%, 21 \%, 27 \%$, and $32 \%$, respectively), despite the comparable $\mathrm{N}_{2} \mathrm{O}$ turnover contributions by the AOB denitrification pathway (33\%) and the $\mathrm{NH}_{2} \mathrm{OH}$ pathway (67\%) in the absence of the HB pathway in each granule size class.

To visualize the volumetric contribution of each granule size class to $\mathrm{N}_{2} \mathrm{O}$ production, the volumetric ratio (in percentage) of each granule size class relative to the total volume of all granule size classes in its respective reactor was calculated and has been added on to Fig. 5. For the reactor with 5 granule size classes free from the HB contribution (Fig. 5D), the volumetric ratio is lower than the $\mathrm{N}_{2} \mathrm{O}$ production contribution in granule size classes with a relatively small granule size (i.e., size classes $1 / 5$ to $3 / 5$ ), while the volumetric ratio is higher than the $\mathrm{N}_{2} \mathrm{O}$ production contribution in granule size classes with a larger granule size (i.e., size classes $4 / 5$ and 5/5). The same trend has been noted for the reactor with 4 granule size classes (Fig. 5C), which only involves marginal negative $\mathrm{N}_{2} \mathrm{O}$ production contribution by the HB pathway. When the number of granule size classes is reduced to 3 in Fig. 5B, the significant negative $\mathrm{N}_{2} \mathrm{O}$ production contribution by the $\mathrm{HB}$ pathway dwarfs the $\mathrm{N}_{2} \mathrm{O}$ production in size class $1 / 3$, thus closing up the discrepancy between the volumetric ratio and the $\mathrm{N}_{2} \mathrm{O}$ production contribution. However, size classes $2 / 3$ and $3 / 3$ still exhibit the pattern similar to Figs. 5C and 5D. When the number of granule size classes is further reduced to 2 in 
Fig. $5 \mathrm{~A}$, the $\mathrm{HB}$ pathway plays a significant role in reducing $\mathrm{N}_{2} \mathrm{O}$ production in both granule size classes. As a consequence, the volumetric ratio is higher than the $\mathrm{N}_{2} \mathrm{O}$ production contribution in size class $1 / 2$, while the volumetric ratio is lower than the $\mathrm{N}_{2} \mathrm{O}$ production contribution in size class 2/2. This trend in Fig. 5A is opposite to the one observed for the reactor with 4 or 5 granule size classes (i.e., Figs. 5C and 5D).

\section{DISCUSSION}

Different from the common practice of assuming a uniform granule size, this work deals with the impact of granule size distribution on the autotrophic granular reactor performing PN/Anammox with focus on the related $\mathrm{N}_{2} \mathrm{O}$ production. This incorporation of granule size distribution into the model enables the description of exchange of solutes between granules of different sizes and is particularly suitable for capturing the reality in reactors without welldistributed granule size. As indicated in Fig. 3, the microbial community structure is significantly influenced by the granule size. In a granular reactor with granule size distribution, granules of different sizes (i.e., different surface/volume ratios) are subject to different ammonium loadings as well as different oxygen availability in the granular structure, which have also been documented by Volcke et al. (2012) when exploring the NOB activity in the one-stage PN/Anammox granular system. These differences govern the competition between HB and Anammox bacteria for nitrite and the competition between HB and AOB for oxygen in the confined space at the granule surface. Therefore, HB tend to be outcompeted in relatively large granules while being retained in a small quantity in smaller granules. This trend is intensified with the higher extent of granule size distribution until the number of granule size classes reaches 5 , where HB are completely washed out of the granules. The discrepancies in microbial community structure lead to distinct $\mathrm{N}_{2} \mathrm{O}$ production rates contributed by different $\mathrm{N}_{2} \mathrm{O}$ production pathways in the granular structure of different 
granule size classes (Fig. 4). The $\mathrm{HB}$ pathway tends to be effective in consuming $\mathrm{N}_{2} \mathrm{O}$ in small granules, while the $\mathrm{AOB}$ denitrification pathway and the $\mathrm{NH}_{2} \mathrm{OH}$ pathway make significant contributions to $\mathrm{N}_{2} \mathrm{O}$ production in granules of different sizes. As a result, different granule size classes contribute differently to the net $\mathrm{N}_{2} \mathrm{O}$ production in the autotrophic granular reactor (Fig. 5). In general, larger granules account for a higher portion of the net $\mathrm{N}_{2} \mathrm{O}$ production in the autotrophic granular reactor. For an autotrophic granular reactor with a relatively high extent of granule size distribution (e.g., 4 or 5 granule size classes in this work), the volumetric contribution of smaller granules to $\mathrm{N}_{2} \mathrm{O}$ production is higher than that of larger granules. Due to the $\mathrm{N}_{2} \mathrm{O}$ production pathway differentiation mainly in the level of the HB pathway, the volumetric contribution of smaller granules decreases with the decreasing extent of granule size distribution. Therefore, the volumetric contribution of smaller granules to $\mathrm{N}_{2} \mathrm{O}$ production is lower than that of larger granules in the autotrophic granular reactor with 2 granule size classes. The overall impact of granule size distribution in Fig. 1 shows that with the increasing extent of granule size distribution (i.e., the increasing number of granule size classes considered), the TN removal efficiency decreases consistently while the $\mathrm{N}_{2} \mathrm{O}$ production factor increases until the number of granule size classes reaches more than 4. It needs to be emphasized that $\mathrm{HB}$ as the minor microbial species growing on microbial decay products have been shown to play an important role in regulating $\mathrm{N}_{2} \mathrm{O}$ production in the autotrophic granular reactor with a varied extent of granule size distribution, while they have no significant impact on the TN removal, which is line with the simulation result reported by Mozumder et al. (2014).

The simulation-based findings obtained in this work have two meaningful implications for the autotrophic nitrogen removal granular reactor, although their validity can only be verified in the future, considering the current unavailability of experimentally documented correlation 
between granule size distribution and $\mathrm{N}_{2} \mathrm{O}$ production. Firstly, the ever-decreasing $\mathrm{TN}$ removal efficiency and the ever-increasing $\mathrm{N}_{2} \mathrm{O}$ production factor with the increasing number of granule size classes (Fig. 1) indicates the necessity of keeping the granules as welldistributed as possible in order to obtain high TN removal whilst minimizing $\mathrm{N}_{2} \mathrm{O}$ production. This might be done through proper hydrodynamic shear control (Bobade et al., 2018). A similar key role of granule size in affecting nitrogen removal as well as regulating $\mathrm{N}_{2} \mathrm{O}$ production has been reported for an Anammox-based granular sludge (Zhu et al., 2018a). Secondly, when modelling $\mathrm{N}_{2} \mathrm{O}$ production/emission from the autotrophic nitrogen removal granular reactor, granule size distribution should be taken into account. For an autotrophic granular reactor with a significant extent of granule size distribution, the consideration of a uniform granule size in modelling might produce a $\mathrm{N}_{2} \mathrm{O}$ production factor lower than its actual level. As shown in Fig. 1, the $\mathrm{N}_{2} \mathrm{O}$ production factor at 1 granule size class is around $40 \%$ lower than that at 5 granule size classes. Considering the significant global warming potential of $\mathrm{N}_{2} \mathrm{O}$, such a discrepancy will substantially alter the reliable prediction of the carbon footprint of the autotrophic granular reactor studied. However, in that case, a total of 4 distinct granule size classes to be considered in the model should be enough to produce the reliable $\mathrm{N}_{2} \mathrm{O}$ production and TN removal, as the continuous increase in the number of granule size classes to 5 only causes less than $0.5 \%$ difference but increases the computational expenses exponentially (see Fig. S3 in the SI). Moreover, both the TN removal efficiency and the $\mathrm{N}_{2} \mathrm{O}$ production factor remain unchanged with the further increase in the number of granule size classes to above 5 (data not shown). On the contrary, one might opt to a uniform granule size (i.e., one granule size class to be considered) when only targeting at the overall nitrogen removal performance of the autotrophic granular reactor, even though the actual size distribution might reflect the reality more closely. This is in view of the minor impact of granule size distribution on the TN removal efficiency (less than $4 \%$ change between 1 and 5 
granule size classes in Fig. 1). This phenomenon is consistent with the finding reported in Volcke et al. (2012), despite the fact that the metabolisms of HB were not accounted for in their work.

It should be noted that the simulated results presented in this work are specific to the model structure and parameter set applied, which were verified in our previous work (Chen et al., 2019). This is inevitable on the premise that there is no generally accepted model which could be used to describe multiple $\mathrm{N}_{2} \mathrm{O}$ production pathways. Even though the model has been shown to be capable of predicting the overall $\mathrm{N}_{2} \mathrm{O}$ production (Chen et al., 2019), its credibility of differentiating $\mathrm{N}_{2} \mathrm{O}$ production pathways remains to be further validated, which will rely significantly on the availability of reliable in-situ tracing techniques applicable to the autotrophic granular reactor studied in this work. In spite of all this, the critical role of granule size distribution in affecting $\mathrm{N}_{2} \mathrm{O}$ production/emission from the autotrophic nitrogen removal granular reactor is undeniable.

\section{CONCLUSIONS}

This work investigated the impact of granule size distribution on the autotrophic granular reactor performing partial nitritation and Anammox with focus on the $\mathrm{N}_{2} \mathrm{O}$ production. Main conclusions include:

$\mathrm{HB}$ growing on microbial decay products tend to be retained and contribute to $\mathrm{N}_{2} \mathrm{O}$ consumption in relatively small granules, while AOB are mainly responsible for $\mathrm{N}_{2} \mathrm{O}$ production via two pathways of AOB in granules of different sizes. Such heterogeneity in the granular structure disappears when the number of granule size classes considered reaches more than 4 , where $\mathrm{HB}$ are completely outcompeted in the granules. 
$>$ Larger granules account for a higher portion of the net $\mathrm{N}_{2} \mathrm{O}$ production, while the trend regarding the volumetric contribution of each granule size class changes with a varied number of granule size classes, due to the different contributions of relevant $\mathrm{N}_{2} \mathrm{O}$ production pathways (with the HB pathway being the most decisive).

With the increasing extent of granule size distribution, the nitrogen removal efficiency decreases slightly but consistently, whereas the $\mathrm{N}_{2} \mathrm{O}$ production factor increases until the number of granule size classes reaches 4 or above.

Practically, granules should be controlled as well-distributed as possible in order to obtain high nitrogen removal (i.e., an efficiency of around 90.0\%) whilst minimizing $\mathrm{N}_{2} \mathrm{O}$ production (i.e., a $\mathrm{N}_{2} \mathrm{O}$ production factor of lower than $2.0 \%$ ).

When modelling $\mathrm{N}_{2} \mathrm{O}$ production/emission from the autotrophic nitrogen removal granular reactor, granule size distribution should be considered carefully and specifically.

\section{ACKNOWLEDGEMENTS}

Dr. Xueming Chen acknowledges the financial support by the European Union's Horizon 2020 research and innovation programme through Marie Skłodowska-Curie Individual Fellowship under grant agreement No. 790231. Dr. Bing-Jie Ni acknowledges the Australian Research Council (ARC) through Future Fellowship FT160100195.

\section{REFERENCES}

Ali, M., Rathnayake, R.M.L.D., Zhang, L., Ishii, S., Kindaichi, T., Satoh, H., Toyoda, S., Yoshida, N., Okabe, S., 2016. Source identification of nitrous oxide emission pathways from a single-stage nitritation-anammox granular reactor. Water Research 102, 147-157. 
Baeten, J.E., van Loosdrecht, M.C.M., Volcke, E.I.P., 2017. Improving the accuracy of granular sludge and biofilm reactor simulations in Aquasim through artificial diffusion. Biotechnology and Bioengineering 114, 2131-2136.

Blum, J.-M., Jensen, M.M., Smets, B.F., 2018. Nitrous oxide production in intermittently aerated Partial Nitritation-Anammox reactor: oxic $\mathrm{N}_{2} \mathrm{O}$ production dominates and relates with ammonia removal rate. Chemical Engineering Journal 335, 458-466.

Bobade, V., Evans, G., Baudez, J.C., Eshtiaghi, N., 2018. Impact of gas injection on physicochemical properties of waste activated sludge: A linear relationship between the change of viscoelastic properties and the change of other physiochemical properties. Water Research 144, 246-253.

Castro-Barros, C.M., Daelman, M.R.J., Mampaey, K.E., van Loosdrecht, M.C.M., Volcke, E.I.P., 2015. Effect of aeration regime on $\mathrm{N}_{2} \mathrm{O}$ emission from partial nitritation-anammox in a full-scale granular sludge reactor. Water Research 68, 793-803.

Chen, X., Ni, B.J., Sin, G., 2019. Nitrous oxide production in autotrophic nitrogen removal granular sludge: A modeling study. Biotechnology and Bioengineering 116(6), 12801291.

Domingo-Félez, C., Mutlu, A.G., Jensen, M.M., Smets, B.F., 2014. Aeration strategies to mitigate nitrous oxide emissions from single-stage nitritation/anammox reactors. Environmental Science \& Technology 48(15), 8679-8687.

Hanaki, K., Hong, Z., Matsuo, T., 1992. Production of Nitrous Oxide Gas during Denitrification of Wastewater. Water Science and Technology 26, 1027-1036.

IPCC, 2014. Climate Change 2014: Synthesis Report. Contribution of Working Groups I, II and III to the Fifth Assessment Report of the Intergovernmental Panel on Climate Change, IPCC, Geneva, Switzerland, p. 151. 
Jetten, M.S.M., Wagner, M., Fuerst, J., van Loosdrecht, M., Kuenen, G., Strous, M., 2001. Microbiology and application of the anaerobic ammonium oxidation ('anammox') process. Current Opinion in Biotechnology 12, 283-288.

Joss, A., Salzgeber, D., Eugster, J., Konig, R., Rottermann, K., Burger, S., Fabijan, P., Leumann, S., Mohn, J., Siegrist, H., 2009. Full-Scale Nitrogen Removal from Digester Liquid with Partial Nitritation and Anammox in One SBR. Environmental Science \& Technology 43, 5301-5306.

Kampschreur, M.J., Poldermans, R., Kleerebezem, R., van der Star, W.R.L., Haarhuis, R., Abma, W.R., Jetten, M.S.M., van Loosdrecht, M.C.M., 2009. Emission of nitrous oxide and nitric oxide from a full-scale single-stage nitritation-anammox reactor. Water Science and Technology 60, 3211-3217.

Kartal, B., Kuenen, J.G., van Loosdrecht, M.C.M., 2010. Sewage Treatment with Anammox. Science 328, 702-703.

Kartal, B., Kuypers Marcel, M.M., Lavik, G., Schalk, J., Op den Camp Huub, J.M., Jetten Mike, S.M., Strous, M., 2006. Anammox bacteria disguised as denitrifiers: nitrate reduction to dinitrogen gas via nitrite and ammonium. Environmental Microbiology 9, 635-642.

Koch, G., Egli, K., Van der Meer, J.R., Siegrist, H., 2000. Mathematical modeling of autotrophic denitrification in a nitrifying biofilm of a rotating biological contactor. Water Science and Technology 41, 191-198.

Kuenen, J.G., 2008. Anammox bacteria: from discovery to application. Nature Reviews Microbiology 6, 320-326.

Kuriqi, A., 2014. Simulink application on dynamic modeling of biological waste water treatment for aerator tank case. Int. J. Sci. Technol. Res 3, 69-72. 
Kuriqi, A., Kuriqi, I., Poci, E., 2016. Simulink programing for dynamic modelling of activated sludge process: Aerator and settler tank case. Fresen. Environ. Bull 25, 2891.

Liu, T., Ma, B., Chen, X., Ni, B.-J., Peng, Y., Guo, J., 2017. Evaluation of mainstream nitrogen removal by simultaneous partial nitrification, anammox and denitrification (SNAD) process in a granule-based reactor. Chemical Engineering Journal 327, 973-981.

Lotti, T., Kleerebezem, R., Hu, Z., Kartal, B., Jetten, M.S.M., van Loosdrecht, M.C.M., 2014. Simultaneous partial nitritation and anammox at low temperature with granular sludge. Water Research 66, 111-121.

Lu, X., D. S. Pereira, T., Al-Hazmi, H.E., Majtacz, J., Zhou, Q., Xie, L., Makinia, J., 2018. Model-Based Evaluation of $\mathrm{N}_{2} \mathrm{O}$ Production Pathways in the Anammox-Enriched Granular Sludge Cultivated in a Sequencing Batch Reactor. Environmental Science \& Technology.

Ma, C., Jensen, M.M., Smets, B.F., Thamdrup, B., 2017. Pathways and Controls of $\mathrm{N}_{2} \mathrm{O}$ Production in Nitritation-Anammox Biomass. Environmental Science \& Technology 51, 8981-8991.

Mozumder, M.S.I., Picioreanu, C., van Loosdrecht, M.C.M., Volcke, E.I.P., 2014. Effect of heterotrophic growth on autotrophic nitrogen removal in a granular sludge reactor. Environmental Technology 35, 1027-1037.

Ni, B.-J., Pan, Y., Guo, J., Virdis, B., Hu, S., Chen, X., Yuan, Z., 2016. Denitrification Processes for Wastewater Treatment, Metalloenzymes in Denitrification, pp. 368-418.

Ni, B.-J., Ruscalleda, M., Smets, B.F., 2012. Evaluation on the microbial interactions of anaerobic ammonium oxidizers and heterotrophs in Anammox biofilm. Water Research $46,4645-4652$. 
Ni, B.J., Yuan, Z.G., 2013. A model-based assessment of nitric oxide and nitrous oxide production in membrane-aerated autotrophic nitrogen removal biofilm systems. Journal of Membrane Science 428, 163-171.

Ravishankara, A.R., Daniel, J.S., Portmann, R.W., 2009. Nitrous Oxide $\left(\mathrm{N}_{2} \mathrm{O}\right)$ : The Dominant Ozone-Depleting Substance Emitted in the 21st Century. Science 326, 123-125.

Reichert, P., 1998. AQUASIM 2.0-Computer program for the identification and simulation of aquatic systems, EAWAG, Dubendorf, Switzerland.

Sabba, F., Picioreanu, C., Nerenberg, R., 2017. Mechanisms of nitrous oxide $\left(\mathrm{N}_{2} \mathrm{O}\right)$ formation and reduction in denitrifying biofilms. Biotechnology and Bioengineering 114, 27532761.

Sabba, F., Picioreanu, C., Pérez, J., Nerenberg, R., 2015. Hydroxylamine Diffusion Can Enhance $\mathrm{N}_{2} \mathrm{O}$ Emissions in Nitrifying Biofilms: A Modeling Study. Environmental Science \& Technology 49, 1486-1494.

Schulthess, R.V., Gujer, W., 1996. Release of nitrous oxide $\left(\mathrm{N}_{2} \mathrm{O}\right)$ from denitrifying activated sludge: Verification and application of a mathematical model. Water Research 30, 521530.

Sliekers, A.O., Derwort, N., Gomez, J.L.C., Strous, M., Kuenen, J.G., Jetten, M.S.M., 2002. Completely autotrophic nitrogen removal over nitrite in one single reactor. Water Research 36, 2475-2482.

Volcke, E.I.P., Picioreanu, C., De Baets, B., van Loosdrecht, M.C.M., 2012. The granule size distribution in an anammox-based granular sludge reactor affects the conversionImplications for modeling. Biotechnology and Bioengineering 109, 1629-1636.

Zhu, G., Wang, S., Ma, B., Wang, X., Zhou, J., Zhao, S., Liu, R., 2018a. Anammox granular sludge in low-ammonium sewage treatment: Not bigger size driving better performance. Water Research 142, 147-158. 
Zhu, T., Xu, B., Wu, J., 2018b. Experimental and mathematical simulation study on the effect of granule particle size distribution on partial nitrification in aerobic granular reactor. Biochemical Engineering Journal 134, 22-29. 


\section{Table and Figure Legends}

Table 1. Features of reactors with different granule size classes implemented in this work

Figure 1. Configuration implemented in Aquasim to model granule size distribution (i.e., $\mathrm{n} \geq$ 2) as presented in this work.

Figure 2. Effect of number of granule size classes on (A) TN removal efficiency and active biomass fraction and (B) $\mathrm{N}_{2} \mathrm{O}$ production factor and contribution of $\mathrm{AOB}$ and $\mathrm{HB}$ pathways to $\mathrm{N}_{2} \mathrm{O}$ turnover.

Figure 3. Profiles of solid components in each size class of granular reactor with (A) 1 , (B and $\mathbf{C})$ 2, (D, E, and F) 3, (G, H, I, and $\mathbf{J}) 4$, and (K, L, M, N, and $\mathbf{O}) 5$ granule size classes.

Figure 4. Profiles of relevant $\mathrm{N}_{2} \mathrm{O}$ production rates in each size class of granular reactor with (A) 1, (B and C) 2, (D, E, and F) 3, (G, H, I, and $\mathbf{J})$ 4, and (K, L, M, N, and $\mathbf{O}) 5$ granule size classes.

Figure 5. Volumetric ratio of each size class with its corresponding contribution to net $\mathrm{N}_{2} \mathrm{O}$ production and associated contribution of each $\mathrm{N}_{2} \mathrm{O}$ production pathway in each size class of granular reactor with (A) 2, (B) 3, (C) 4, and (D) 5 granule size classes. 
Table 1. Features of reactors with different granule size classes implemented in this work

\begin{tabular}{|c|c|c|c|c|c|c|}
\hline \multirow{4}{*}{$\begin{array}{l}\text { Scenario 1 } \\
\text { Reactor with } 1 \\
\text { granule size } \\
\text { class }\end{array}$} & & Size class $1 / 1$ & & & & \\
\hline & Compartment volume $\left(\mathrm{m}^{3}\right)$ & 1 & & & & \\
\hline & Number of granules & $3.82 \times 10^{8}$ & & & & \\
\hline & Granule radius $(\mu \mathrm{m})$ & 500 & & & & \\
\hline \multirow{4}{*}{$\begin{array}{l}\text { Scenario 2 } \\
\text { Reactor with } 2 \\
\text { granule size } \\
\text { classes }\end{array}$} & & Size class $1 / 2$ & Size class $2 / 2$ & & & \\
\hline & Compartment volume $\left(\mathrm{m}^{3}\right)$ & 0.33333333 & 0.33333333 & & & \\
\hline & Number of granules & $1.91 \times 10^{8}$ & $1.91 \times 10^{8}$ & & & \\
\hline & Granule radius $(\mu \mathrm{m})$ & 420 & 560 & & & \\
\hline \multirow{4}{*}{$\begin{array}{l}\text { Scenario } 3 \\
\text { Reactor with } 3 \\
\text { granule size } \\
\text { classes }\end{array}$} & & Size class $1 / 3$ & Size class $2 / 3$ & Size class $3 / 3$ & & \\
\hline & Compartment volume $\left(\mathrm{m}^{3}\right)$ & 0.25 & 0.25 & 0.25 & & \\
\hline & Number of granules & $1.27 \times 10^{8}$ & $1.27 \times 10^{8}$ & $1.27 \times 10^{8}$ & & \\
\hline & Granule radius $(\mu \mathrm{m})$ & 350 & 490 & 600 & & \\
\hline \multirow{4}{*}{$\begin{array}{c}\text { Scenario } 4 \\
\text { Reactor with } 4 \\
\text { granule size } \\
\text { classes }\end{array}$} & & Size class $1 / 4$ & Size class $2 / 4$ & Size class $3 / 4$ & Size class $4 / 4$ & \\
\hline & Compartment volume $\left(\mathrm{m}^{3}\right)$ & 0.2 & 0.2 & 0.2 & 0.2 & \\
\hline & Number of granules & $9.55 \times 10^{7}$ & $9.55 \times 10^{7}$ & $9.55 \times 10^{7}$ & $9.55 \times 10^{7}$ & \\
\hline & Granule radius $(\mu \mathrm{m})$ & 290 & 430 & 540 & 620 & \\
\hline \multirow{4}{*}{$\begin{array}{c}\text { Scenario 5 } \\
\text { Reactor with } 5 \\
\text { granule size } \\
\text { classes }\end{array}$} & & Size class $1 / 5$ & Size class $2 / 5$ & Size class $3 / 5$ & Size class $4 / 5$ & Size class $5 / 5$ \\
\hline & Compartment volume $\left(\mathrm{m}^{3}\right)$ & 0.16666667 & 0.16666667 & 0.16666667 & 0.16666667 & 0.16666667 \\
\hline & Number of granules & $7.64 \times 10^{7}$ & $7.64 \times 10^{7}$ & $7.64 \times 10^{7}$ & $7.64 \times 10^{7}$ & $7.64 \times 10^{7}$ \\
\hline & Granule radius $(\mu \mathrm{m})$ & 260 & 380 & 490 & 570 & 630 \\
\hline
\end{tabular}




\section{Highlights}

Impact of granule size distribution on autotrophic granular $\mathrm{N}_{2} \mathrm{O}$ production was studied.

Heterogeneity in granular structure weakens with extent of granule size distribution.

$>\mathrm{HB}$ washout due to elevated granule size distribution increases $\mathrm{N}_{2} \mathrm{O}$ production factor. 


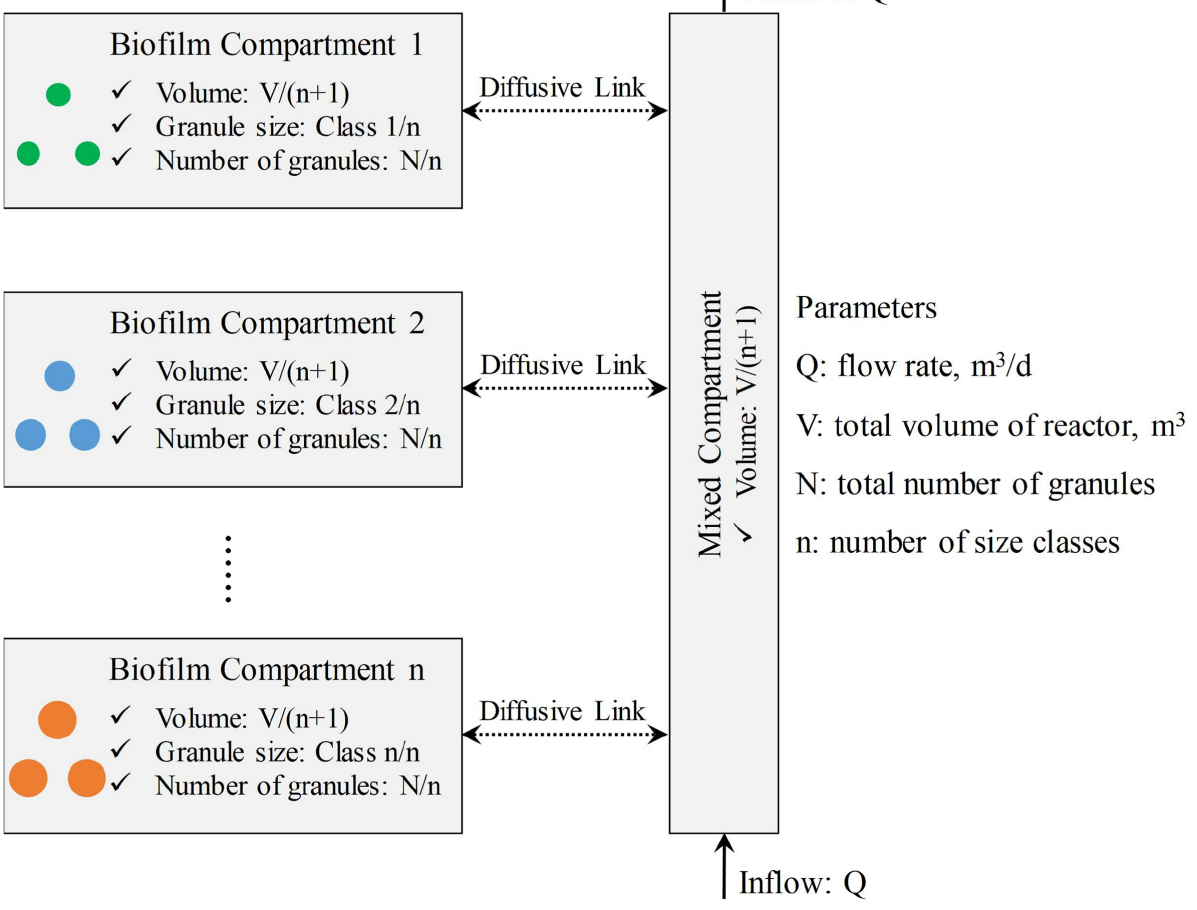

Figure 1 


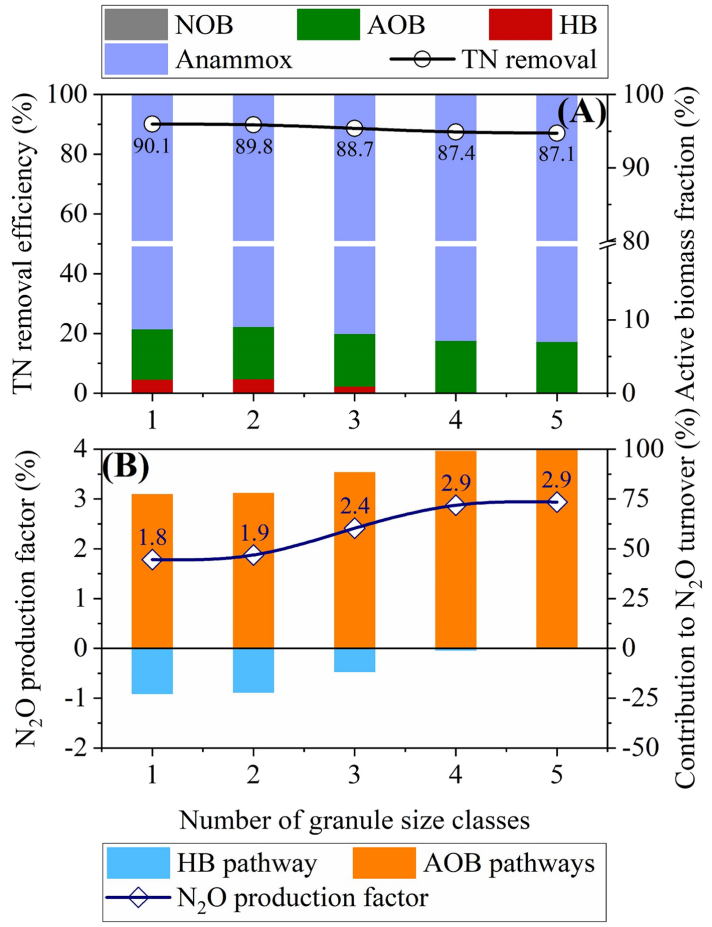

Figure 2 


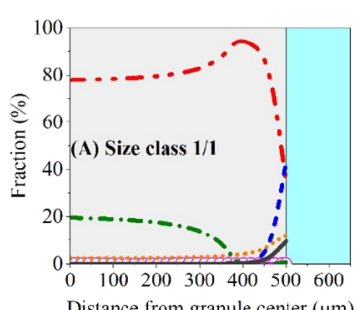

\section{Legends:}

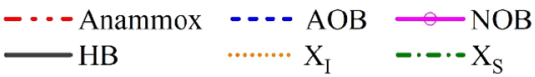

Distance from granule center $(\mu \mathrm{m})$
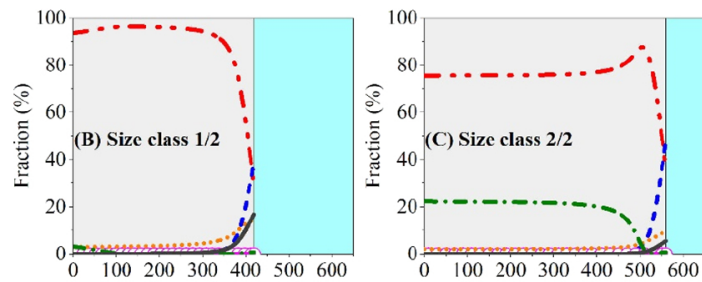

Distance from granule center $(\mu \mathrm{m})$

Distance from granule center ( $\mu$ m)
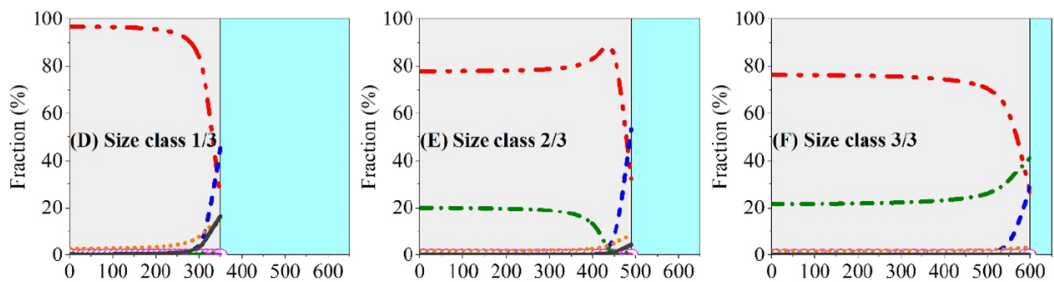

Distance from granule center $(\mu \mathrm{m})$
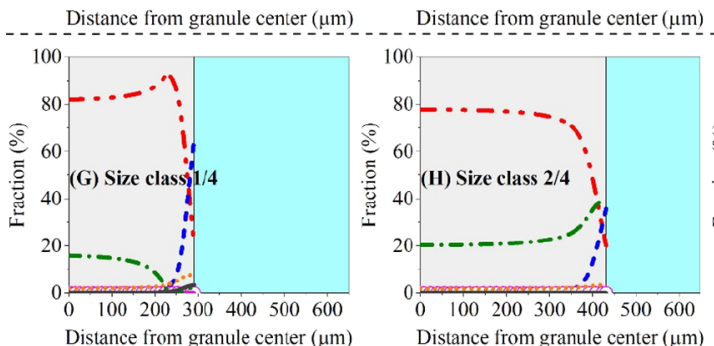

Distance from granule center $(\mu \mathrm{m})$
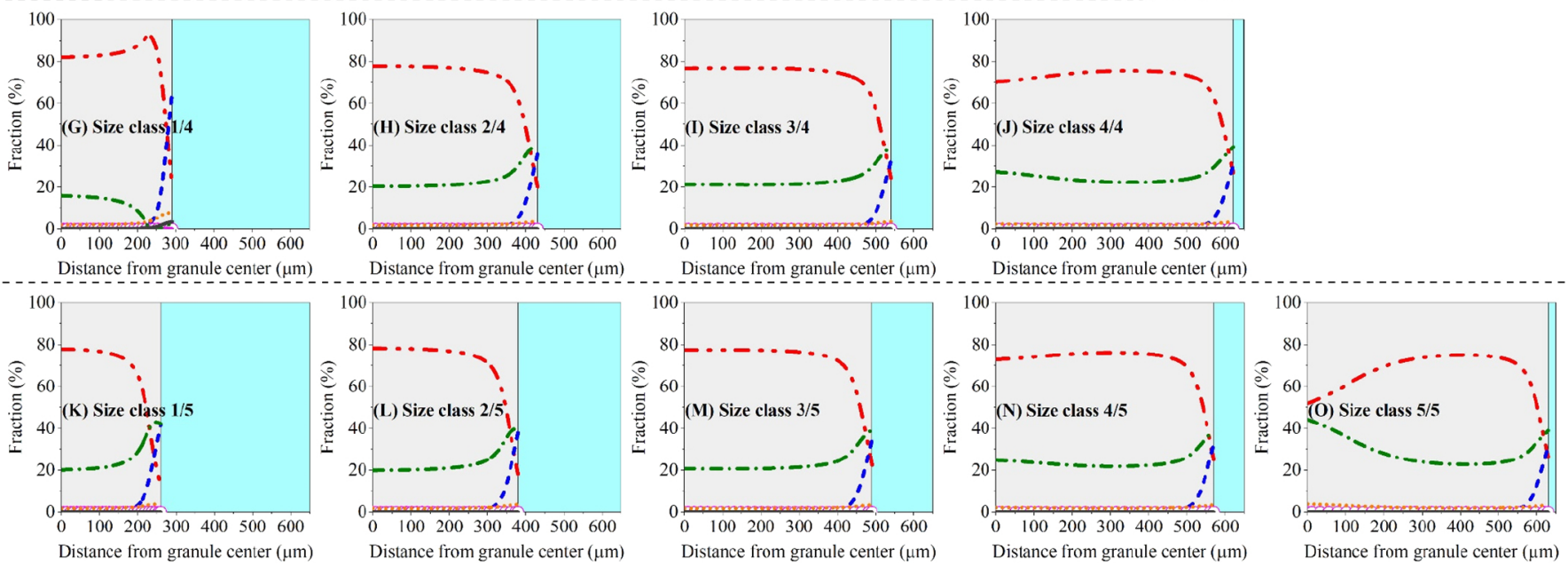

Figure 3 


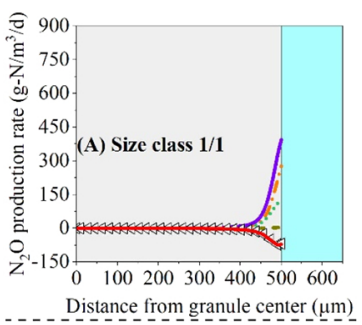

_ . . . Distance from granule center $(\mu \mathrm{m})$
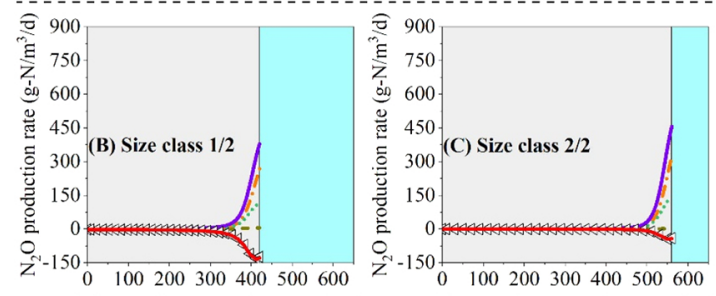

Distance from granule center (um) Distance from granule center $(\mu \mathrm{m})$
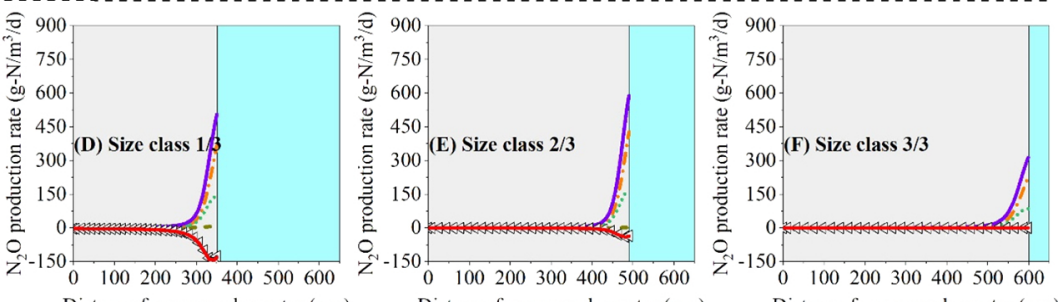

Distance from granule center $(\mu \mathrm{m})$

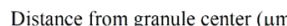

Distance from
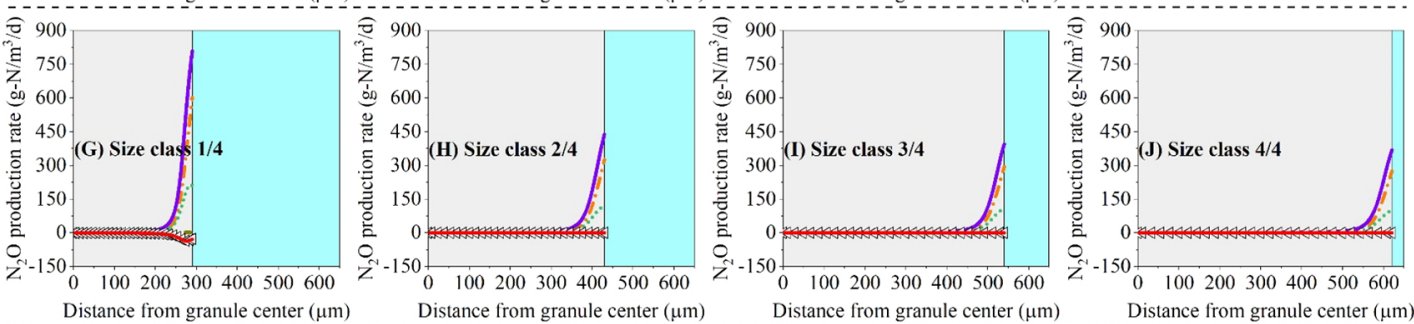

Distance from granule center $(\mu \mathrm{m})$
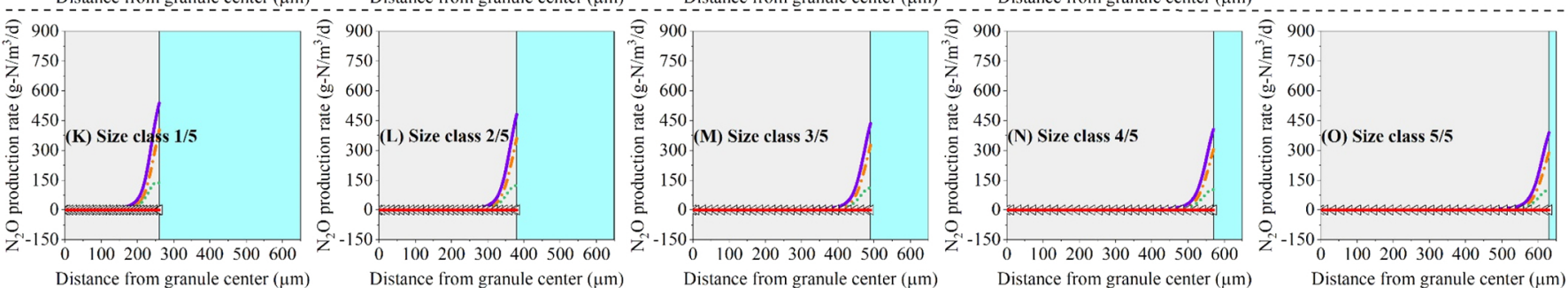

Figure 4 


\begin{tabular}{|lll|}
\hline & Hydroxylamine pathway & AOB denitrification pathway \\
\hline & HB pathway & Contribution of size class \\
$\Delta \quad$ & Volumetric ratio of size class & \\
\hline
\end{tabular}

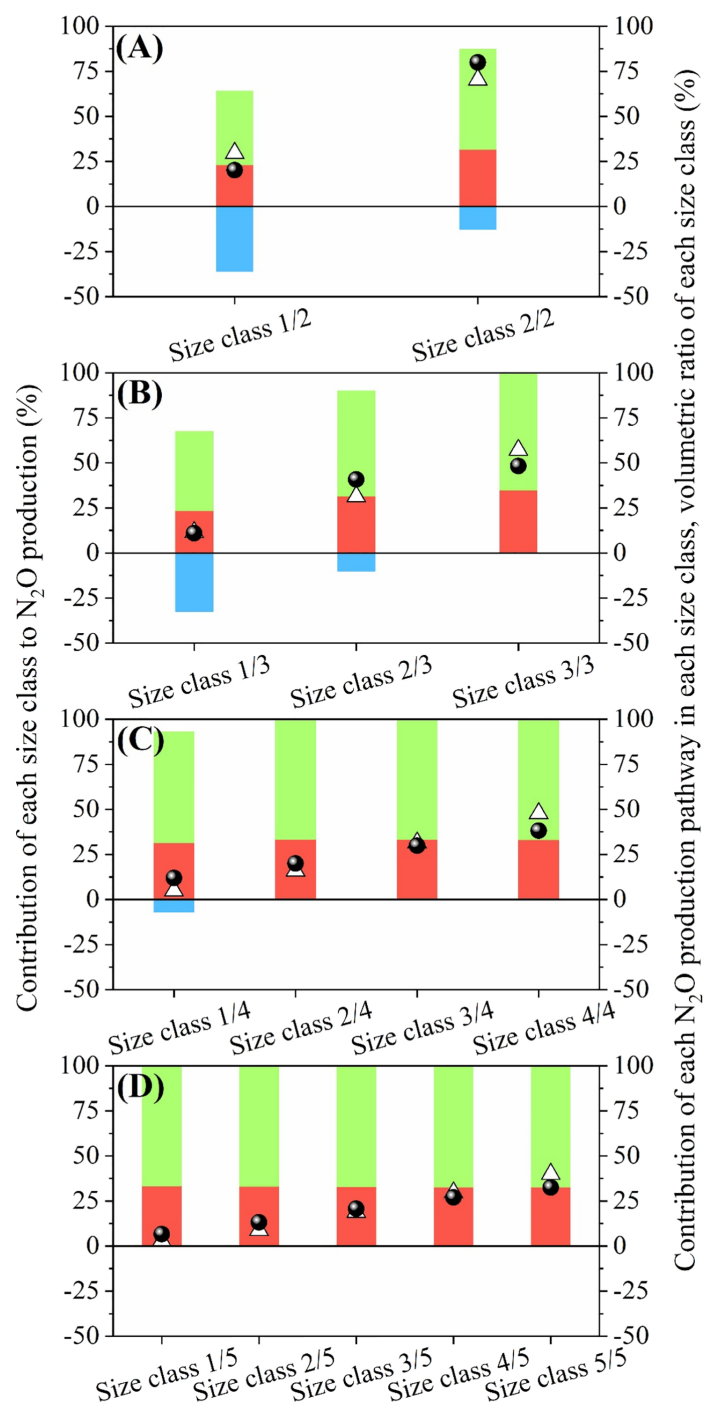

Figure 5 